\title{
METODE PEMBUATAN SORGUM SOSOH RENDAH TANIN PADA PEMBUATAN NASI SORGUM (Sorghum bicolor L) INSTAN
}

\author{
Wiwit Amrinola ${ }^{1}$; Sri Widowati ${ }^{2}$; Purwiyatno Hariyadi ${ }^{3}$ \\ ${ }^{1}$ Industrial Engineering Department, Faculty of Engineering, BINUS University \\ Jalan KH Syahdan No.9 Palmerah, Jakarta 11480, Indonesia \\ ${ }^{2}$ Peneliti Balai Besar Penelitian dan Pengembangan Pascapanen Pertanian Bogor \\ ${ }^{3}$ Departemen Ilmu dan Teknologi Pertanian IPB \\ 11wiwit_zahra@yahoo.com
}

\begin{abstract}
Sorghum is one of the non-rice commodities which have a relatively high content of nutrients, especially protein and carbohydrate. However, the nutritional value is to be down and relatively low due to the relatively high tannin content as an anti-nutrient. Fairly high tannin content in sorghum is also causing sorghum has unpleasant taste and slightly bitter or "Sepet". Therefore, it is necessary to reduce the content of tannins in sorghum that is expected to improve the quality of nutrition, especially the increase in protein and starch digestibility and palatability or the flavor of sorghum products. The purpose of this study is to obtain the best method to lower tannin content in the manufacture of low-tannin sorghum milling, which will be used in the manufacture of instant rice sorghum. This research was done in two stages, namely 1) the timing of the milling stage and 2) the development stage of a method of making low-tannin sorghum milling by comparing the content of tannin reduction method with the immersion process in alkaline solution $(\mathrm{NaOH} 0.3 \%$ and $0.3 \% \mathrm{Na} 2 \mathrm{CO} 3)$ and distilled water with the method of reducing tannin content without immersion process. The results of this study indicate that the best milling time that can produce milled sorghum with good physical sorghum is five minutes and the best immersion treatment that can lower the optimum tannin content is by immersing in $0.3 \%$ Na2CO3 solution for 24 hours. This method can reduce up to $77.46 \%$ tannin content.
\end{abstract}

Keywords: milled sorghum, decrease tannin content, immersion process

\begin{abstract}
ABSTRAK
Sorgum merupakan salah satu komoditi non beras yang memiliki kandungan gizi cukup tinggi, terutama protein dan karbohidratnya. Namun nilai gizi ini menjadi turun dan relatif rendah karena adanya kandungan tanin yang cukup tinggi sebagai zat anti gizi. Kandungan tanin yang cukup tinggi pada sorgum ini juga menyebabkan sorgum memiliki rasa yang kurang enak dan agak pahit "sepet". Oleh karena itu, maka diperlukan upaya untuk mereduksi kandungan tanin pada sorgum sehingga diharapkan dapat meningkatkan mutu gizi, terutama peningkatan daya cerna protein dan pati, serta palatabilitas atau citarasa produk sorgum. Tujuan penelitian ini adalah untuk mendapatkan metode menurunkan kandungan tanin terbaik dalam pembuatan sorgum sosoh rendah tanin, yang akan digunakan dalam pembuatan nasi sorgum instan. Penelitian ini dilakukan dengan dua tahap, yaitu 1) tahap penentuan waktu penyosohan dan 2) tahap pengembangan metode pembuatan sorgum sosoh rendah tanin dengan cara membandingkan metode penurunan kandungan tanin dengan proses perendaman dalam larutan alkali ( $\mathrm{NaOH} 0.3 \%$ dan $\mathrm{Na}_{2} \mathrm{CO}_{3} 0.3 \%$ ) dan aquadest dengan metode penurunan kandungan tanin tanpa proses perendaman. Dari penelitian ini diperoleh hasil bahwa waktu penyosohan terbaik yang dapat menghasilkan sorgum sosohan dengan keragaan yang baik adalah 5 menit dan perlakuan perendaman terbaik yang dapat menurunkan kandungan tanin secara optimum adalah perendaman dalam larutan $\mathrm{Na}_{2} \mathrm{CO}_{3} 0.3 \%$ selama 24 jam. metode ini dapat menurunkan kandungan tanin hingga $77.46 \%$.
\end{abstract}

Kata kunci: sorgum sosoh, penurunan kandungan tanin, proses perendaman. 


\section{PENDAHULUAN}

Masalah pengadaan beras sebagai bahan pangan sumber karbohidrat di Indonesia hingga saat ini masih belum teratasi sepenuhnya. Salah satu penyebab keadaan ini adalah karena 95\% penduduk Indonesia mengutamakan beras sebagai makanan pokok. Saat ini konsumsi beras nasional perkapita mencapai $139.15 \mathrm{~kg} / \mathrm{kapita} / \mathrm{tahun}$ dan merupakan konsumsi terbesar se Asia Tenggara (Triyatna, 2012), sedangkan idealnya adalah 80 - $90 \mathrm{~kg} / \mathrm{kapita} / \mathrm{tahun}$ (Firdaus et al., 2008). Salah satu solusi terhadap permasalahan pangan tersebut adalah dengan melakukan diversifikasi pangan pada menu harian. Hal ini dilakukan untuk menghindari ketergantungan pada satu jenis bahan pangan seperti beras dan peningkatan mutu gizi konsumsi pangan. Selain itu, konsumsi pangan yang beragam akan saling melengkapi kekurangan zat gizi tertentu dari satu jenis pangan dengan pangan lainnya (Khomsan, 2006). Produk pangan yang dapat digunakan untuk diversifikasi beras salah satunya adalah sorgum.

Sorgum merupakan salah satu komoditi non beras yang dapat tumbuh di daerah tropis dan subtropis. Menurut Widowati dkk (2009), nilai gizi sorgum tidak kalah dengan beras. Sorgum mengandung protein (8-12\%) setara dengan terigu atau lebih tinggi dibandingkan dengan beras (610\%), dan kandungan lemaknya (2-6\%) lebih tinggi dibandingkan dengan beras (0.5-1.5\%). Pengadopsian teknologi pemanfaatan sorgum masih terbatas karena citra sorgum sebagai komoditas inferior dan memiliki rasa yang kurang enak dan agak pahit "sepet" karena kandungan taninnya yang cukup tinggi (berkisar antara 2.7-10.2\% catechin equivalent) (Suprapto dan Mudjisihono, 1987). Kandungan tanin pada sorgum mempunyai efek antioksidan sehingga produk olahannya dapat dijadikan sebagai produk pangan fungsional. Namun selain mempunyai sifat antioksidan, tanin juga mempunyai efek antigizi.

Tanin yang terdapat pada biji sorgum merupakan tanin dalam bentuk terkondensasi. Tanin dalam bentuk ini mampu memproduksi kompleks yang lebih stabil dibandingkan dengan tanin dalam bentuk terhidrolisis. Tanin merupakan komponen phenolik yang dapat berfungsi sebagai antioksidan bagi tubuh, namun di sisi lain juga bersifat sebagai antigizi bagi tubuh. Tanin merupakan senyawa yang larut dalam air dan memiliki kemampuan berikatan dengan protein sehingga membentuk kompleks dengan protein serta mampu menurunkan mutu dan daya cerna protein (Von Elbe dan Schwartz, 1996). Tanin juga mampu berikatan dengan polimer lainnya seperti polisakarida (pati) sehingga menjadi lebih sukar dicerna oleh enzim pencernaan terutama amilase dan tripsin karena terjadinya penurunan aktivitas enzim tersebut (Griffiths dan Moseley, 1980; Despandhe dan Salunkhe, 1982).

Oleh karena itu, meskipun kandungan gizi sorgum (terutama protein dan karbohidrat) cukup tinggi dan lebih baik dari beras, namun nilai gizi ini menjadi turun dan relatif rendah karena adanya kandungan tanin yang cukup tinggi sebagai zat antigizi. Untuk mengubah citra sorgum menjadi komoditas superior yang dilirik sebagai pengganti beras dan disukai masyarakat, maka diperlukan upaya untuk mereduksi kandungan tanin pada sorgum sehingga diharapkan dapat meningkatkan mutu gizi, terutama peningkatan daya cerna protein dan pati, serta palatabilitas atau cita rasa produk sorgum. Peningkatan mutu gizi dan daya cerna sorgum setelah perlakuan penurunan kandungan tanin memungkinkan sorgum menjadi produk pangan pokok harapan selain beras dan jagung.

Kendala lain yang dihadapi dalam pemanfaatan sorgum sebagai bahan pangan adalah teknik penyosohan biji sorgum. Meskipun telah banyak dikembangkan alat penyosoh sorgum, namun palatabilitas sorgum masih rendah akibat masih cukup tinggi nya kandungan tanin sorgum sosoh setelah mengalami proses penyosohan dengan alat sosoh yang sudah dikembangkan. Oleh karena itu, metode reduksi tanin pada sorgum perlu diteliti hingga taraf palatabilitasnya dapat diterima konsumen, namun masih mempunyai efek fungsional bagi kesehatan tubuh. 
Selain pereduksian kandungan tanin sebagai upaya peningkatan mutu gizi sorgum sebagai bahan pangan pokok harapan, citra sorgum juga perlu ditingkatkan menjadi produk pangan bergengsi dan mengikuti tren pasar. Salah satu upaya yang dapat dilakukan adalah menjadikannya sebagai produk pangan instan fungsional seperti nasi sorgum instan. Pangan pokok instan yang sudah dikembangkan adalah nasi instan dari beras dan nasi jagung instan, sedangkan nasi sorgum instan belum diteliti.

Kandungan tanin pada bahan makanan dapat diturunkan dengan berbagai cara seperti perendaman, perebusan, fermentasi, dan penyosohan kulit luar biji. Menurut Hubeis (1984), Pengolahan sorgum dapat dilakukan dengan berbagai cara, diantaranya dengan proses penggilingan. Proses penggilingan sorgum menjadi beras sorgum serupa dengan penggilingan beras dari padi atau gabah, tapi perbedaannya adalah sorgum tidak dikuliti/dikupas dengan penggilingan rol karet. Hal ini karena sorgum tidak mempunyai sekam. Pembuatan beras sorgum dilakukan dengan tahapan membersihkan bahan, lalu melakukan tindak "conditioning" atau "tempering" dan selanjutnya menyosoh sorgum selama beberapa waktu pada alat sosoh hingga menjadi beras sorgum. Beras sorgum yang dihasilkan tersebut masih tercampur dengan bentuk butiran tidak utuh dan dedak, maka pemisahan fraksinya dilakukan dengan pengayakan secara manual atau masinal.

Suprapto dan Mudjisihono (1987) menjelaskan bahwa kandungan tanin pada biji sorghum dapat diturunkankan dengan cara perendaman air suling pada suhu $30{ }^{\circ} \mathrm{C}$ selama 24 jam. Kadar tanin yang hilang dengan metode ini sekitar 31\%. Perendaman dalam larutan $\mathrm{NaOH}$ dan $\mathrm{KOH}$ 0,05M pada suhu $30^{\circ} \mathrm{C}$ selama 24 jam dapat menghilangkan kandungan tanin lebih besar yaitu sekitar $75-85 \%$. Perendaman dengan $\mathrm{Na}_{2} \mathrm{CO}_{3}$ pada kondisi yang sama dapat menghilangkan tanin sebesar $77 \%$. Kehilangan tanin pada beberapa perlakuan di atas diduga akibat terkelupasnya kulit biji dan hilangnya lapisan testa selama perlakuan. Chavan et a.l (1979) melaporkan bahwa perlakuan pemanasan dengan suhu $100{ }^{\circ} \mathrm{C}$ dapat mengurangi waktu perendaman dari 24 jam menjadi 20 jam. lebih jauh El Fadel et al. (1993) melaporkan bahwa perendaman biji sorgum dalam larutan $\mathrm{Na}_{2} \mathrm{CO}_{3}$ selama 24 jam pada suhu $30^{\circ} \mathrm{C}$ atau pemanasan pada suhu $100^{\circ} \mathrm{C}$ selama 20 menit menggunakan larutan $\mathrm{Na}_{2} \mathrm{CO}_{3}$, dapat menurunkan kadar tanin dan meningkatkan daya cerna protein secara in vitro sebesar $90 \%$.

Tujuan penelitian ini adalah untuk mendapatkan metode penurunan kandungan tanin terbaik dalam pembuatan sorgum sosoh rendah tanin yang akan digunakan dalam pembuatan nasi sorgum instan dengan cara membandingkan metode penurunan kandungan tanin dengan proses perendaman dengan metode penurunan kandungan tanin tanpa proses perendaman.

\section{METODE}

\section{Alat dan Bahan}

Bahan baku utama yang digunakan dalam penelitian adalah biji sorgum non-waxes dari varietas yang memiliki kadar tanin tinggi dan produktivitas tinggi, yaitu varietas ZH-30 yang diperoleh dari Univesitas Padjajaran, Bandung. Bahan lain yang digunakan adalah larutan garam alkali ( $\mathrm{NaOH} 0.3 \%$ dan $\mathrm{Na}_{2} \mathrm{CO}_{3} 0.3 \%$ ), aquadest, dan bahan-bahan kimia yang digunakan untuk analisis yang berasal dari E-Merk atau Sigma Aldrich.

Alat-alat yang digunakan dalam penelitian ini terdiri dari alat gelas dan non gelas. Instrumen yang digunakan pada penelitian ini adalah alat penyosoh beras tipe Satake dengan batu gerinda tipe Amril no. 50, pH-meter, chromameter, timbangan analitik, kiya hardness meter, alat tanak nasi konvensional skala laboratorium, oven, tanur pengabuan, hot plate, water bath, refrigerator, freezer, dan spektrofotometer. 
Penelitian ini terdiri dari dua tahap penelitian. Penelitian tahap I merupakan tahap penentuan waktu penyosohan dan penelitian tahap II merupakan tahap pengembangan metode pembuatan sorgum sosoh rendah tanin. Rancangan percobaan yang digunakan adalah acak lengkap dengan 3 kali ulangan. Kemudian data hasil pengamatan diolah menggunakan analisis sidik ragam (ANOVA). Jika terjadi beda nyata pada faktor perlakuan pada selang kepercayaan 95\%, dilanjutkan dengan uji beda Duncan.

\section{Penelitian Tahap I (Penentuan Waktu penyosohan)}

Pembuatan sorgum sosoh diawali dengan pembersihan biji sorgum dari material selain biji sorgum, selanjutnya biji sorgum yang telah bersih tersebut degrading, hal ini bertujuan untuk mendapatkan biji sorgum dengan ukuran yang seragam. Setelah grading, dilakukan proses conditioning, dan selanjutnya biji sorgum disosoh dengan alat sosoh.

Penentuan waktu penyosohan pada penelitian tahap I bertujuan untuk menghasilkan sorgum sosoh yang baik (rendemen tinggi, keutuhan sorgum sosoh, dan warna). Selain penentuan waktu penyosohan, pada penelitian tahap I ini juga dilakukan karakterisasi bahan baku yang akan digunakan dan penentuan kadar air yang tepat saat proses penyosohan. Penentuan waktu penyosohan penentuan kadar air bertujuan untuk menghasilkan sorgum sosoh yang baik (rendemen tinggi, keutuhan sorgum sosoh, dan warna). Karakterisasi bahan baku yang dilakukan adalah analisa proksimat (Kadar protein, lemak, karbohidrat, abu, dan kadar air), dan analisa kandungan tanin biji sorgum utuh.

Penentuan waktu penyosohan (WP) dilakukan pada tiga tingkat waktu yang berbeda, yaitu WP1, WP2, dan WP3. Setelah penyosohan, dilakukan pengayakan yang bertujuan untuk memisahkan sorgum sosoh utuh, patah, menir dan dedak.

Penelitian Tahap II (Pengembangan metode pembuatan sorgum sosoh rendah tanin)

Sorgum sosoh yang diperoleh dari hasil penelitian tahap I diberi perlakuan penurunan kandungan tanin dengan cara perendaman di dalam larutan alkali ( $\mathrm{NaOH} 0.3 \%$ dan $\left.\mathrm{Na}_{2} \mathrm{CO}_{3} 0.3 \%\right)$ dan tanpa larutan alkali atau hanya dengan air destilata (aquadest) saja selama 8 jam, 16 jam, dan 24 jam. Dari tahapan di atas, diperoleh sorgum sosoh rendah tanin yang akan digunakan pada tahap pembuatan nasi sorgum instan selanjutnya. Jumlah sampel yang digunakan untuk masing-masing perlakuan adalah $200 \mathrm{~g}$ biji sorgum. Diagram alir proses pembuatan sorgum sosoh kering rendah tanin dapat dilihat pada Gambar 1 berikut.

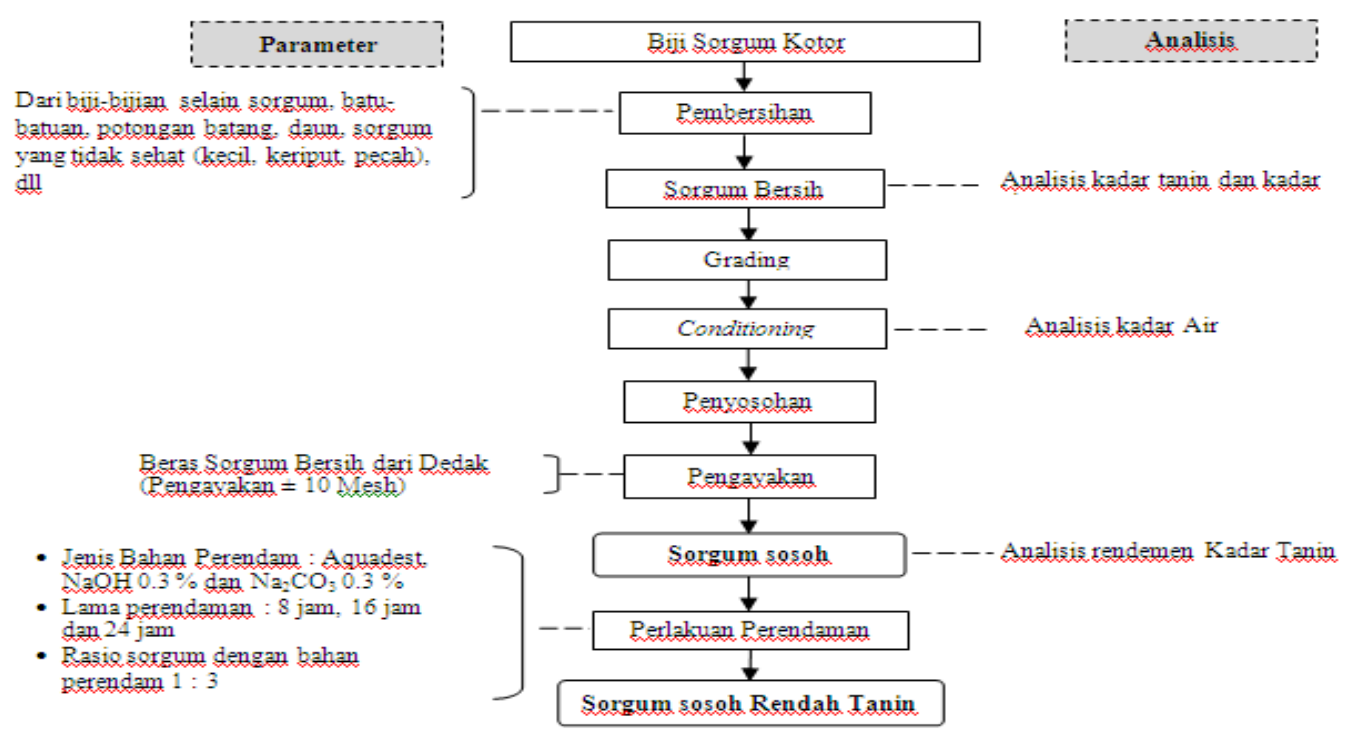

Gambar 1 Diagram Alir Pembuatan Sorgum Sosoh Rendah Tanin 


\section{HASIL DAN PEMBAHASAN}

\section{Karakterisasi Bahan Baku}

Karakterisasi bahan baku (biji sorgum) yang digunakan pada penelitian ini dilakukan terhadap komposisi kimia dan warna. Komposisi kimia biji sorgum utuh yang digunakan sebagai bahan baku pembuatan nasi instan dapat dilihat pada Tabel 1.

Tabel 1 Komposisi kimia biji sorgum utuh varietas ZH-30

\begin{tabular}{lc}
\hline \multicolumn{1}{c}{ Komponen } & \% Kandungan \\
\hline Karbohidrat (\% bk) & 83.24 \\
Protein (\% bk) & 12.85 \\
Lemak (\% bk) & 2.71 \\
Abu (\% bk) & 1.20 \\
Kadar Air (\% bk) & 9.42 \\
Kandungan Tanin (\% bk Tannic Acid Equivalent) & 3.34 \\
\hline
\end{tabular}

Keterangan : bk $=$ Basis kering

Berdasarkan hasil analisa komposisi kimia biji sorgum pada Tabel 1 di atas dapat dilihat bahwa biji sorgum varietas ZH-30 memiliki kandungan gizi yang sangat tinggi, terutama kandungan protein, karbohidrat. Suprapto dan Mudjisihono (1987) menyatakan bahwa kandungan protein biji sorgum berbagai varietas yang ada di Indonesia berkisar antara 7-10\%. Protein sorgum sama seperti biji serealia lainnya yang terdiri dari albumin, globulin, dan prolamin. Albumin adalah protein yang dapat larut dalam air, globulin larut dalam larutan garam, dan prolamin larut dalam alkohol.

Komposisi zat gizi biji sorgum yang tinggi tersebut dalam penggunaannya dapat dihambat oleh senyawa tanin (turunan polifenol). Kandungan tanin sorgum sering dihubungkan dengan warna kulit luar (testa) yang gelap. Menurut Suprapto dan Mudjisihono (1987), biji sorgum yang memiliki kandungan tanin tinggi dicirikan dengan warnanya yang coklat gelap atau coklat kemerahan. Dari hasil analisis derajat putih (whiteness) atau warna menggunakan alat Chromameter menunjukkan bahwa derajat putih (whiteness) sorgum vaietas ZH-30 adalah 83.74\%. secara visual, warna dan bentuk biji sorgum utuh dapat dilihat pada Gambar 2.

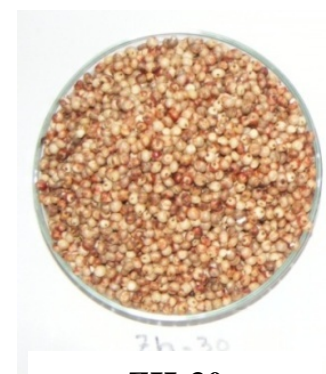

ZH-30

Gambar 2 Biji Sorgum Utuh Yang Digunakan Dalam Penelitian 


\section{Proses Penyosohan}

\section{Penentuan Waktu Penyosohan (WP)}

Semakin lama waktu penyosohan, maka rendemen yang dihasilkan akan semakin turun karena lapisan aleuron dan testa yang dapat dipisahkan menjadi lebih banyak. Semakin lama waktu penyosohan, maka keragaan sorgum sosoh yang dihasilkan lebih banyak yang patah (sorgum sosoh utuh lebih sedikit). Hasil analisis rendemen pada waktu penyosohan dua hingga lima menit dapat dilihat pada Tabel 2.

Tabel 2 Rendemen sorgum sosoh pada berbagai waktu penyosohan

\begin{tabular}{cc}
\hline Waktu (Menit) & Rendemen (\%) \\
\hline 2 & 81.0 \\
2.5 & 76.4 \\
3 & 74.2 \\
4 & 71.9 \\
5 & 68.2 \\
\hline
\end{tabular}

Biji sorgum terdiri dari 7.3-9.3\% kulit luar, 7.8-12.1\% lembaga, dan 80-84.6\% endosperm. Kulit luar terdiri dari epikarp, mesokarp, dan endocarp. Epikarp adalah bagian terluar yang tersusun atas dua atau tiga lapisan memanjang, ada yang mengandung pigmen (Hubbard et al., 1950). Rooney dan Miller (1982) menyatakan bahwa mesokarp merupakan lapisan tengah dan cukup tebal, berbentuk poligonal serta mengandung sedikit granula pati. Endocarp tersusun oleh sel menyilang dan sel berbentuk tabung, akan rusak selama proses penggilingan yang menghilangkan kulit luar. Di bawah lapisan perikarp terdapat lapisan kulit biji (testa). Lapisan testa terdapat di bawah endocarp dan di sekeliling permukaan endosperm biji.
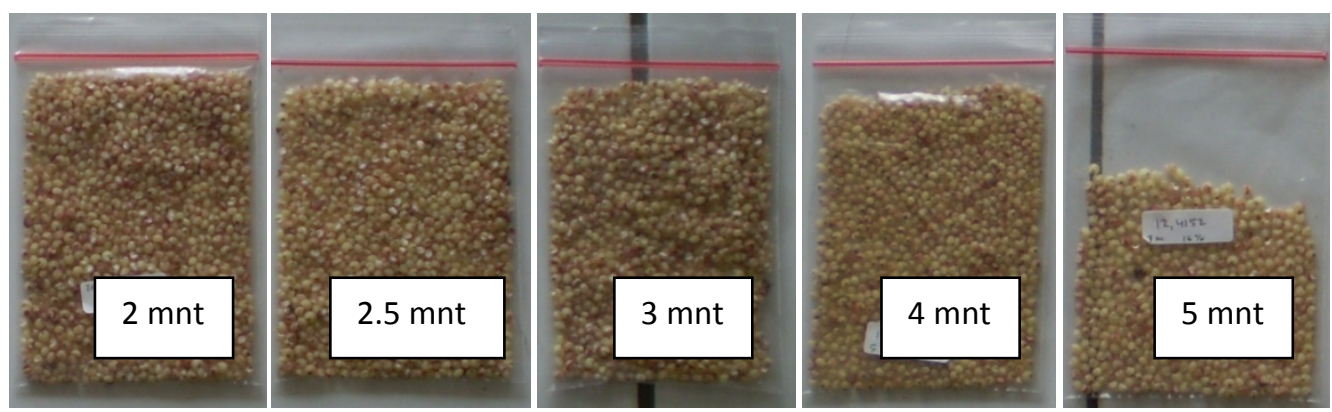

Gambar 3 Sorgum Sosoh yang Dihasilkan

Berdasarkan persentase rendemen yang dihasilkan pada percobaan penentuan waktu penyosohan biji sorgum dan keragaan hasil sosohan, maka waktu penyosohan (WP) yang digunakan dalam proses penyosohan biji sorgum adalah 5 menit sebagai standar untuk waktu penyosohan (WP1), 4 menit untuk WP2 dan 3 menit untuk WP3.

\section{Penentuan Kadar Air yang Tepat untuk Penyosohan Biji Sorgum}

Conditioning" atau "tempering” yang bertujuan untuk mendapatkan kondisi dan kadar air yang tepat pada saat penyosohan dan selanjutnya menyosoh sorgum selama beberapa waktu dengan alat sosoh hingga menjadi sorgum sosoh (Hubeis, 1984). Kadar air biji sorgum saat disosoh 
berpengaruh terhadap rendemen dan mutu giling. Biji sorgum mempunyai kadar air rata-rata $12 \%$, dan saat disosoh, hasil sosohan banyak yang hancur. Untuk memperbaiki rendemen dan mutu giling, dilakukan pengkondisian pada kadar air 14, 16, 20, dan 22\%. Hasil analisa terhadap tingkat kadar air dengan rendemen sorgum sosoh dapat dilihat pada Gambar 4.

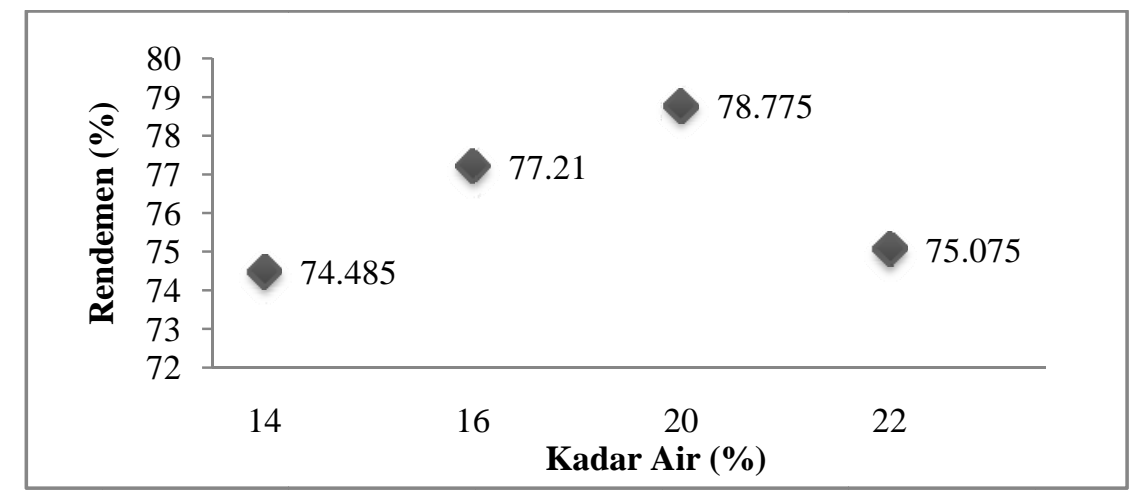

Gambar 4 Pengaruh Kadar Air Biji Sorgum Utuh Saat Penyosohan Terhadap Rendemen Sorgum Sosohan

Kadar air berpengaruh terhadap keliatan dan kekuatan dari beras sorgum yang dihasilkan. Semakin meningkat kadar air saat penyosohan maka akan menghasilkan sorgum sosoh yang liat dan tidak mudah patah, selain itu juga menyebabkan endosperm menjadi lunak dan lengket. Sebagai pembanding, kadar air ideal untuk gandum saat penyosohan adalah antara 13-16\% . Beta et al. (2000) melaporkan bahwa kadar air yang dibutuhkan biji sorgum sebelum disosoh adalah $12 \%$ untuk biji berkadar tanin rendah dan sedang, sedangkan untuk biji sorgum yang berkadar tanin tinggi adalah $16 \%$.

Dari hasil analisa, diperoleh kadar air terbaik untuk menghasilkan rendemen sorgum sosoh tertinggi adalah pada kadar air 20\% yang disosoh selama 5 menit (WP1). Kadar air dan waktu penyosohan ini digunakan sebagai acuan pada proses penyosohan biji sorgum yang telah diberi perlakuan pendahuluan pada langkah selanjutnya.

\section{Pengembangan Metode Pembuatan Sorgum Sosoh Rendah Tanin}

Parameter yang digunakan pada penentuan perlakuan pembuatan sorgum sosoh rendah tanin ini adalah persentase penurunan kandungan tanin. Proses penyosohan dilakukan dengan alat sosoh beras tipe Satake yang menggunakan batu gerinda tipe Amril No. 50. Penyosohan dilakukan pada tiga waktu penyosohan (WP) yang berbeda, yaitu 5 menit (WP1), 4 menit (WP2), dan 3 menit (WP3). Setelah itu, sorgum sosoh yang dihasilkan barulah diberikan perlakuan penurunan kandungan tanin dengan perendaman dalam larutan $\mathrm{NaOH} 0.3 \%$, larutan $\mathrm{Na}_{2} \mathrm{CO}_{3} 0.3 \%$, dan dalam air destilata.

\section{Pembuatan Sorgum Sosoh Rendah Tanin Tanpa Perlakuan Perendaman}

Tanin merupakan senyawa fenolik yang larut di dalam air dan memiliki kemampuan berikatan dengan protein, dan polimer lainnya seperti polisakarida (Von Elbe dan Schwartz, 1996). Sebagai bahan pangan, sorgum mempunyai komposisi zat gizi yang tinggi terutama kandungan karbohidrat dan proteinnya, namun biji sorgum merupakan salah satu jenis bahan makanan yang juga memiliki kandungan tanin yang cukup tinggi, yaitu berkisar antara 2.7-10.2\% catechin equivalent. Dalam penggunaannya, zat gizi yang terdapat dalam biji sorgum tersebut dapat dihambat oleh senyawa tanin (turunan polifenol). Senyawa tanin bersifat menghambat kerja enzim pencernaan dan disamping itu melindungi biji sorgum dari hama (Hubeis, 1984). Komposisi gizi sorgum yang cukup tinggi dapat 
dimanfaatkan secara optimal dengan cara menurunkan kandungan taninnya. Upaya yang dapat dilakukan untuk menurunkan kandungan tanin pada biji sorgum diantaranya adalah dengan cara penyosohan kulit luar biji, perendaman, perebusan dan fermentasi.

Hasil analisa penurunan kandungan tanin sorgum sosoh tanpa perlakuan perendaman dapat dilihat pada Gambar 5. Perbedaan waktu penyosohan akan menurunkan kandungan tanin dalam jumlah yang berbeda juga. Semakin lama waktu penyosohan, maka kandungan tanin yang dapat dihilangkan akan semakin besar pula. Dengan waktu penyosohan (WP) yang berbeda, penurunan kandungan tanin biji sorgum yang paling banyak diperoleh dengan melakukan penyosohan pada WP1, selanjutnya berturut-turut diikuti oleh WP2 dan WP3. Waktu penyosohan (WP1, WP2, dan WP3) dapat menurunkan kandungan tanin berturut-turut sebesar 35.89\%, 29.99\%, dan 11.13\%. Semakin lama waktu penyosohan, dapat menyebabkan semakin banyak lapisan testa terkikis dan semakin banyak pula kandungan tanin yang ikut terkikis akibat proses penyosohan tersebut. .

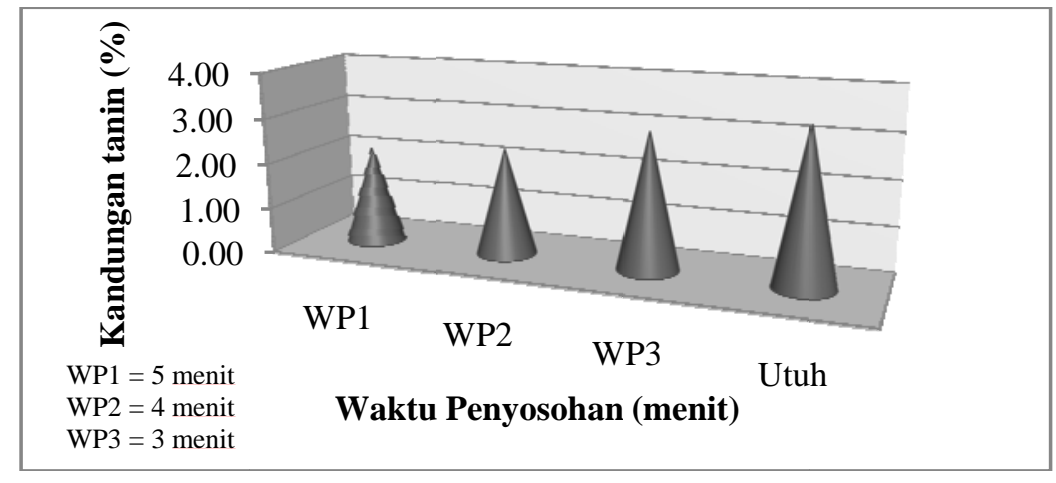

Gambar 5 Pengaruh Waktu Penyosohan (Menit) terhadap Kandungan Tanin Sorgum Sosoh yang Dihasilkan

\section{Pembuatan Sorgum Sosoh Rendah Tanin Dengan Perlakuan Perendaman}

Suprapto dan Mudjisihono (1987) menjelaskan bahwa kandungan tanin pada biji sorghum dapat diturunkankan dengan cara perendaman air suling pada suhu $30{ }^{\circ} \mathrm{C}$ selama 24 jam. Kadar tanin yang hilang dengan metode ini sekitar 31\%. Perendaman dalam larutan $\mathrm{NaOH}$ dan $\mathrm{KOH}$ 0,05M pada suhu $30{ }^{\circ} \mathrm{C}$ selama 24 jam dapat menghilangakan kandungan tanin lebih besar sekitar $75-85 \%$. Perendaman dengan $\mathrm{Na}_{2} \mathrm{CO}_{3}$ pada kondisi yang sama dapat menghilangkan tanin sebesar $77 \%$. Kehilangan tanin pada beberapa perlakuan di atas diduga akibat terkelupasnya kulit biji dan hilangnya lapisan testa selama perlakuan. Chavan et a.l (1979) melaporkan bahwa perlakuan pemanasan dengan suhu $100{ }^{\circ} \mathrm{C}$ dapat mengurangi waktu perendaman dari 24 jam menjadi 20 jam. lebih jauh El Fadel dan Abdullah (1993) melaporkan bahwa perendaman biji sorgum dalam larutan $\mathrm{Na}_{2} \mathrm{CO}_{3}$ selama 24 jam pada suhu $30{ }^{\circ} \mathrm{C}$ atau pemanasan pada suhu $100{ }^{\circ} \mathrm{C}$ selama 20 menit menggunakan larutan $\mathrm{Na}_{2} \mathrm{CO}_{3}$, dapat menurunkan kadar tanin dan meningkatkan daya cerna protein secara in vitro sebesar $90 \%$.

Setelah proses penyosohan dilakukan proses perendaman dalam larutan garam alkali dan air destilata. Perlakuan perendaman dalam larutan garam basa bekerja lebih efektif untuk menurunkan kandungan tanin pada biji sorgum setelah dilakukan penyosohan terlebih dahulu. Hal ini karena sebelum diberikan perlakuan penurunan kandungan tanin, kulit luar biji sorgum atau lapisan testanya sudah hilang akibat proses penyosohan, sehingga penurunan kandungan tanin menjadi lebih optimal dan sebagian besar komponen tanin yang ada pada biji sorgum telah terkikis akibat proses penyosohan tersebut, dan tanin yang tersisa pada sorgum sosoh menjadi lebih sedikit daripada biji utuh, sehingga pemutusan ikatan hidrogen-oksigen dan pembentukan Na-Fenolat (garam) pada senyawa tanin tersebut menjadi lebih mudah. 
Hasil analisa penurunan kandungan tanin dengan menggunakan tiga jenis bahan perendam yang berbeda menunjukkan bahwa perlakuan terbaik diperoleh dengan melakukan proses penyosohan terlebih dahulu pada WP1 dan dilanjutkan dengan perlakuan perendaman dalam larutan $\mathrm{Na}_{2} \mathrm{CO}_{3} 0.3 \%$ selama 24 jam. Metode ini dapat menurunkan kandungan tanin sorgum hingga $77.46 \%$ ( dari 3.34 menjadi $0.75 \%$ Tannic acid equivalent), sedangkan dengan $\mathrm{NaOH}$ dan air destilata, maksimal dapat menurunkan kandungan tanin hingga $69.3 \%$ dan $53.45 \%$. Hasil analisa penurunan kandungan tanin dengan perlakuan perendaman ini dapat dilihat pada Gambar 6 berikut.

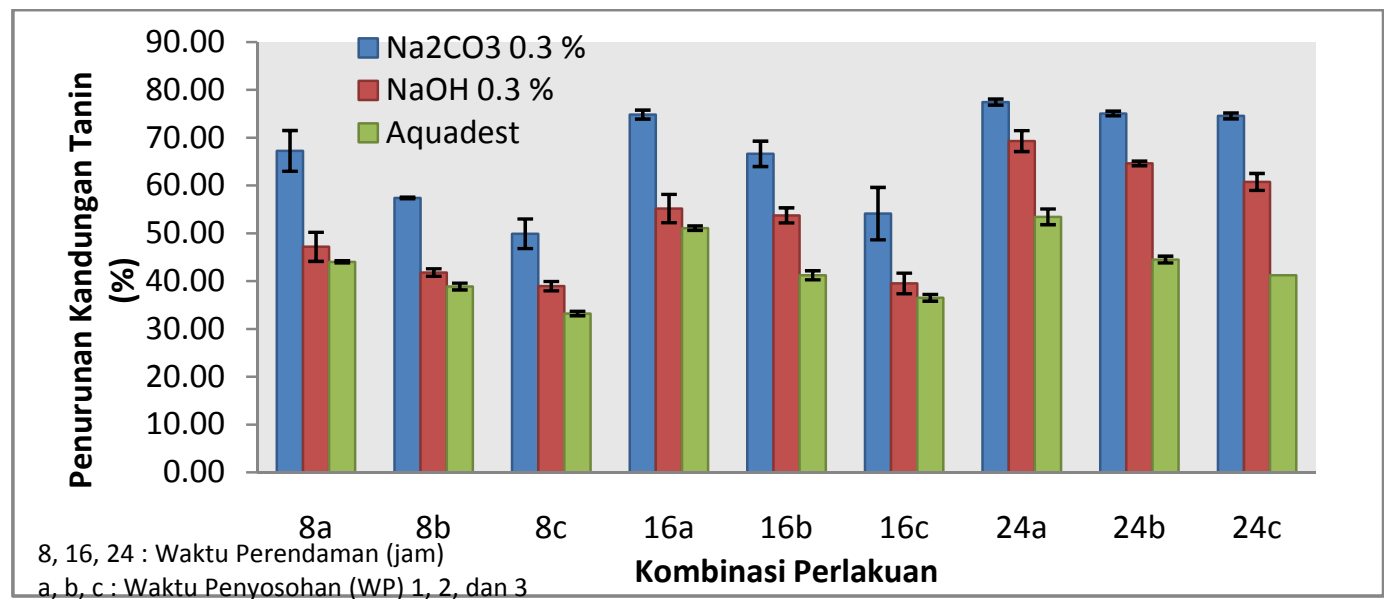

Gambar 6 Pengaruh Kombinasi Perlakuan Penurunan Kandungan Tanin Terhadap Persentase Penurunan Kandungan Tanin Sorgum Sosoh

Penurunan kandungan tanin pada biji sorgum selain disebabkan karena proses penyosohan juga dipengaruhi oleh proses perendaman dalam larutan alkali. Larutan garam alkali menyebabkan ikatan hidrogen-oksigen pada senyawa tanin menjadi putus, sehingga terbentuk Na-Fenolat (garam) dan karbonat yang merupakan asam lemah akan mengalami ionisasi (Fessenden dan Fessenden, 1986). Tanin merupakan senyawa fenolik yang berasal dari benzen dengan suatu gugus $-\mathrm{OH}$ yang terikat pada cincin aromatik. Fenol bersifat asam, stabil, dan mampu bereaksi dengan basa membentuk NaFenolat (garam). Perendaman biji sorgum dalam larutan alkali menyebabkan terjadinya reaksi oksidasi, sehingga membentuk larutan keruh (tanin menjadi larut), karena adanya energi yang bekerja dan terjadi pelepasan elektron oleh suatu atom ketika reaksi sedang berlangsung. Perbedaan warna larutan perendam yang dihasilkan selama proses perendaman dapat dilihat pada Gambar 7.
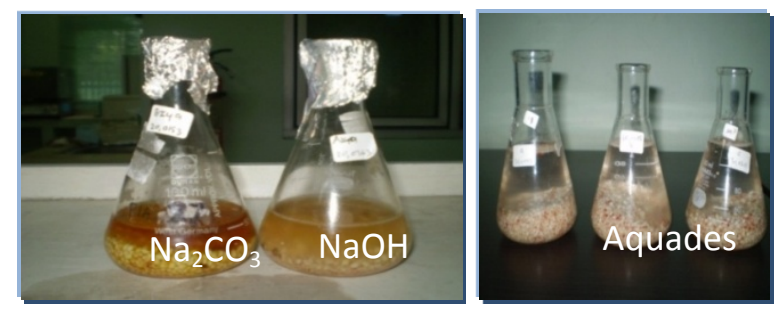

Gambar 7 Perbedaan Warna Larutan Dengan Bahan Perendam Berbeda

Sorgum sosoh rendah tanin yang diperoleh pada penelitian ini dengan perlakuan terbaik selanjutnya digunakan sebagai bahan baku pembuatan nasi sorgum instan rendah tannin pada tahap selanjutnya. 


\section{SIMPULAN}

Dari penelitian yang sudah dilakukan diperoleh kesimpulan bahwa (1) Kadar air biji sorgum yang sesuai saat penyosohan adalah $20 \pm 1 \%$. Pada kadar air tersebut diperoleh rendemen tinggi dan tingkat keutuhan sorgum sosoh lebih tinggi dibandingkan biji sorgum yang disosoh pada tingkat kadar air $12-18 \%$. (2) Waktu penyosohan terbaik yang dapat menghasilkan sorgum sosohan dengan keragaan yang baik adalah 5 menit. Semakin lama waktu perendaman, maka efektifitas penurunan kandungan tanin menjadi lebih tinggi, atau kandungan tanin pada sorgum sosoh menjadi lebih kecil. (3) perlakuan perendaman terbaik yang dapat menurunkan kandungan tanin secara optimum adalah perendaman dalam larutan $\mathrm{Na}_{2} \mathrm{CO}_{3} 0.3 \%$ selama 24 jam. Metode ini dapat menurunkan kandungan tanin hingga $77.46 \%$.

Untuk penelitian lanjutan dalam pembuatan nasi sorgum instan rendah tanin, disarankan menggunakan bahan perendam lain (selain $\mathrm{HaOH}$ dan $\mathrm{Na}_{2} \mathrm{CO}_{3}$ ) yang tidak hanya berpengaruh pada proses instanisasi namun juga dapat menurunkan kandungan tanin secara sekaligus sehingga proses pembuatan nasi sorgum instan menjadi lebih efisien dan efektif.

\section{DAFTAR PUSTAKA}

Beta, T., et al. (2000). Effect of Chemical Conditioning on The Milling of High-Tannin Sorghum. J. Sci. Food and Agric, 80 (15), 2216-2222.

Chavan, J. K., Kadam, S. S., Ghonsikar, C. P., Salunkhe, D. K. (1979). Removal of Tannins and Improvement of In Vitro Protein Digestibility of Sorghum Seeds By Soaking in Alkali. $J$. Food Sci, 44 (5), 1319-1322.

El Fadel EB, Abdullah ET. (1993). Effect of Soaking in Water or in Sodium Carbonate on Tannin Content and In Vitro Protein Digestibility of Sorghum Cultivars. International J. Food Sci. and Techn 28 (4) : 389-395.

Fessenden, R. J., Fessenden, J. S. (1986). Kimia Organik. ed ke-3. Jilid 1. Jakarta: Erlangga.

Firdaus, M., Lukman, M. B., Purwiyanti, P. (2008). Swasembada Beras Dari Masa Ke Masa: Telaah Efektivitas Kebijakan dan Perumusan Strategi Nasional. Bogor: IPB Press.

Griffiths, D. W., Moseley, G. (1980). The effect of diets containing field beans of high or low polyphenolic content on the activity of digestive enzymes in the intestines of rats. J Sci Food Agric, 31, 255-259.

Hubbard, J. K., Hall, H. H., Earle, F. R. (1950). Composition of The Component Parts of Sorghum Kernel. Cereal Chem, 27.

Hubeis, M. (1984). Pengantar pengolahan tepung serealia dan biji-bijian. Bogor. Jurusan Teknologi Pangan dan Gizi Fateta IPB.

Khomsan, A. (2006). Beras dan diversifikasi pangan. Diakses 09 Feb 2008, dari http://kompas.com/kompas-cetak/0612/21/opini/-3190395.htm

Rooney, L. W., Miller, F. R. (1982). Variation in The Structure and Kernel Characteristics of Sorghum. Proceesing of The Symposium on Sorghum, 1, 28 - 31 Oktober 1981. 
Suprapto, H. S., Mudjisihono, R. (1987). Budidaya dan Pengolahan Sorgum. Penebar Swadaya.

Triyatna, S. O. (2012). Konsumsi Beras Indonesia Tertinggi di Asia Tenggara. Diakses pada 7 Februari 2012 dari http://bisniskeuangan.kompas.com/read/2012/02/07/21065277/Konsumsi.Beras.Indonesia.Tert inggi.di.Asia.Tenggara.

Von Elbe, J. H., Schawartz, S. J. (1996). Colorants. Dalam Fennema, O. R (Ed). Food Chemistry, $3^{\text {nd }}$ ed. New York: Marcel Dekker, Inc.

Widowati, S., Santosa, B. A. S., Lubis, S., Herawati, H. dan Nurdjanah, R. (2009). Peningkatan Mutu Penyosohan (80\%) dengan Kandungan Tanin Turun Hingga 1\% dalam Tepung Sorgum dan Pengembangan Produk Sorgum Instan. Laporan Hasil Penelitian. BB Litbang Pascapanen Pertanian. 